\title{
PENERIMAAN PENONTON PEREMPUAN MENGENAI KECANTIKAN PEREMPUAN MELALUI CORPORATE ADVERTISING SK II “BARE SKIN PROJECT"
}

\author{
Florence Pusung $^{1^{*}}$, Brigitta Revia ${ }^{2}$, Yuli Nugraheni ${ }^{3}$ \\ ${ }^{1,2,3}$ Fakultas Ilmu Komunikasi Universitas Katolik Widya Mandala Surabaya \\ Jalan Dinoyo 42-44, Surabaya, 60265 \\ *Penulis korespondensi; Email: 1'florenceladyroses@gmail.com; ${ }^{2}$ gita@ukwms.ac.id; ${ }^{3}$ yulinugraheni@ukwms.ac.id
}

\begin{abstract}
ABSTRAK
Penelitian ini bertujuan untuk mengetahui bagaimana penerimaan penonton perempuan mengenai kecantikan melalui Corporate Advertising SK II "Bare Skin Project". Analisis dan pembahasan diarahkan pada bagaimana penerimaan penonton perempuan iklan korporat SK II "Bare Skin Project” yang menyatakan bagaimana pada masa sekarang ini setiap perempuan memiliki peluang yang sama dalam menjadi cantik, yakni cantik tanpa menggunakan makeup. Dengan menggunakan teori Public Relations, Iklan Korporat sebagai alat Public Relations, juga teori akan kecantikan. Pendekatan yang digunakan yaitu kualitatif, dengan metode reception analysis. Hasil penelitian yang muncul lewat empat sub bab yang ada yaitu yang pertama terkait keinginan untuk cantik alami, yang kedua yakni bangga dengan kulit wajah alami tanpa makeup, ketiga yaitu penggunaan skincare pada kecantikan perempuan serta yang keempat yakni ideal cantik pada iklan. Dengan hasil, keempat informan berada pada posisi oppositional yang berarti menolak pesan dan makna yang diberikan oleh SK II serta satu informan yang berada pada posisi negotiated yang berarti menerima namun dengan kondisi tertentu.
\end{abstract}

Kata kunci: Penerimaan, Corporate Advertising, Reception Analysis

\begin{abstract}
The analysis and discussion in this journal focuses on the acceptance of female audiences about beauty is seen from corporate advertising by SK II "Bare Skin Project". Describe about how womans accept the message of corporate advertising SK II "Bare Skin Project" that are said how womans now had equals chances on being beautiful, which is without makeup. Using the theories from Public Relations, Corporate Advertising as tools of Public Relations and beauty theories. Approach that are use is qualitative with reception analysis as the method. The result that are comes from four sub chapter. First one is the wish to be natural beauty, second is proud with natural skin without makeup, third is the use of skincare on womans beauty, then fourth is the ideal of natural beauty from the advertisement. With the result, as four respondent are on the oppositional side which means they refused the message of SK II and one respondent is accepting the message but with a certain condition.
\end{abstract}

Keywords: Acceptance. Corporate Advertising, Reception Analysis.

\section{PENDAHULUAN}

Fenomena penggunaan media sosial yang kian menjadi banyak sudah tidak asing lagi didengar pada kalangan masyarakat kini, penggunaan bermacammacam platform media sosial sebagai sarana dalam menyampaikan kreatifitas, salah satunya kecantikan, yang kini kian ramai ditemui, mulai dari banyaknya bermunculan tutorial makeup hingga review produkproduk kecantikan tersebut via online. Salah satu sarana promosi yang tentunya sudah tidak asing lagi dan sering ditemui di berbagai macam media seperti televisi, radio, dan bahkan media online seperti website maupun YouTube disebut dengan iklan. Sebuah iklan dibuat dengan tujuan tertentu yang ingin dicapai oleh perusahaan tersebut, bahkan terkadang lebih dari sekedar mempromosikan produk tersebut juga. Berbagai cara pun dilakukan untuk mencapai tujuan tersebut mulai dari konsep dan tema iklan, penggunaan bintang iklan tertentu, serta pemilihan lokasi dan waktu penayangan dari iklan tersebut semua ditata sedemikian rupa. Khususnya iklan-iklan produk kecantikan.

Iklan-iklan produk kecantikan yang juga merupakan pesaing daripada produk SK II ialah seperti milik Clinique, Loccitane dan Kiehls. Namun pada laman resmi mereka sama sekali tidak memiliki Corporate Advertising yang menonjol seperti yang dimiliki oleh SK II. Namun, hanya banyak mengandung video tutorial dalam penggunaan produk skincare nya saja. Iklan-iklan tersebut terkesan repetitive namun tetap memiliki satu tujuan yang sama, yakni mendorong para perempuan untuk bisa cantik lebih natural. 
Konsep iklan dan campaign yang diusung oleh SK II Bare Skin Project jika ditarik merujuk latar belakang juga filosofi milik perusahaan SK II, akan memperlihatkan bahwa perusahaan SK II sangat mendorong kaum perempuan untuk percaya diri dalam cantik yang natural. Pada laman resmi SK II juga menyebutkan terkait arti kecantikan yang dipegang teguh oleh perusahaan SK II, yakni menghadirkan produk perawatan kulit yang menyeluruh, sesuai dengan kondisi kulit, dan membuat kulit tampak bening seperti kristal, begitu juga filosofi SK II yakni menghadirkan teknologi untuk membantu mempelajari kondisi kulit dan mendukung agar kulit nampak bening seperti kristal.

Mengacu pada filosofi, makna kecantikan dan segala bentuk filosofi perusahaan SK II pada perempuan baik dari segi produk hingga kepada iklan yang telah dibuat, dapat dilihat pada identitas perusahaan (corporate identity). Di dalam sebuah buku karya Jefkins yang berjudul Periklanan (1997:296) menjelaskan bahwa identitas dari suatu perusahaan ialah suatu hal yang memungkinkan perusahaan dapat dikenali maupun dibedakan dari perusahaan-perusahaan lainnya. Identitas tersebut harus diciptakan terlebih dahulu lewat suatu rancangan desain khusus yang meliputi segala hal khas/unik berkenaan dengan perusahaan secara fisik.

Sebuah cara yang dapat digunakan perusahaan SK II dalam melahirkan identitas perusahaan lewat iklan korporat. Dalam Jefkins (1997: 287-289) suatu iklan korporat dapat mengangkat kepentingan bisnis atau perusahaan sehingga khalayak dan pihak lain mengetahuinya. Sehingga dapat dilihat disini bahwa iklan prestise untuk perusahaan atau iklan institusional, advokasi/himbauan atau iklan untuk memacu suatu isu, penawaran akuisisi atau pengambil alihan kepemilikan badan usaha, pemoles citra, serta iklan keuangan. Iklan prestise meliputi iklan-iklan pembentuk citra yang sebenarnya yang merupakan suatu bentuk hubungan masyarakat dari perusahaan yang bersangkutan.

Konsep kecantikan pada perempuan telah berevolusi menjadi bagian dari budaya populer masyarakat dunia yang dipuja dan didambakan. Bahkan tak sedikit perempuan yang mengorbankan cukup banyak uang untuk memperoleh kecantikan. Oleh karenanya, tidak heran ditemukan banyak perempuan banyak menghabiskan uang miliknya untuk nampak cantik ideal. Dalam hal ini, peneliti menemukan produsen produk kecantikan yang memiliki konsep iklan berbeda daripada produk kecantikan lainnya. Yaitu perusaha- an SK II yang berasal dari Jepang dan berpusat di Jepang. SK II sendiri muncul pada tahun 1980an dan memiliki perusahaan induk yakni Procter and Gamble ( $\mathrm{P} \& \mathrm{G})$ dan menjual berbagai macam skincare premium di seluruh Asia, Amerika, Eropa dan Australia. SK II sendiri memiliki sejarah dalam perkembangannya sebagai sebuah brand.

Dalam penelitian ini, peneliti berfokus pada salah satu iklan dari SK II yakni SK II Bare Skin Project. Yang mana menurut peneliti menampilkan teks bahwa konsep cantik seorang perempuan bukan hanya putih, bertubuh langsing, berambut lurus dan Panjang tetapi justru beragam dan bahkan tanpa make up. Menurut Hall (2005:125-127), terdapat paradigma yang dapat menjelaskan penerimaan/pemaknaan seseorang terhadap sebuah konsep yaitu paradigma encodingdecoding. Karena adanya perbedaan kosep kecantikan pada iklan SK II Bare Skin Project dengan konsep kecantikan yang dikonstruksi media, maka peneliti ingin melihat bagaimana perempuan menerima, memahami dan memaknai pesan dalam iklan tersebut.

\section{TEORI}

\subsection{Penerimaan Pesan (message reception)}

Teks media terhadap khalayak bukanlah makna yang melekat pada teks media tersebut, tetapi makna diciptakan dalam interaksi antar khalayak dengan teks. Yang berarti makna diciptakan karena khalayak dapat memproses teks media. Media atau komunikator dari iklan tidak dapat lagi melihat komunikan akan memaknai sebuah pesan sesuai dengan apa yang diharapkan oleh komunikator tersebut, suatu pesan dapat diterima penerima, namun dapat juga mengalami kegagalan untuk mencapai tujuan dikarenakan subyektivitas dan interpretasi yang dapat berbeda pada penerima. Oleh karena itu, dalam mengetahui penerimaan khalayak (penonton) yang berbeda-beda. Dalam analisis resepsi terdapat metode yakni encoding-decoding milik Stuart Hall (Pujileksono, 2016: 168-169).

\subsection{Iklan Korporat sebagai Alat Public Relations}

Seperti penjelasan Gassing di atas, untuk mencapai tujuan suatu organisasi, setiap proses harus dilalui oleh praktisi PR. Salah satunya ialah program kerja berupa promosi dan pemasaran. Dalam melakukan promosi dan pemasaran, terdapat banyak alat yang dapat digunakan oleh Public Relations, salah satunya yakni iklan atau dalam hal ini disebut "Public Relations Advertising", yang kemudian dikelompok- 
kan menjadi beberapa yakni Public Relations advertising, institutional advertising, corporate identity advertising, dan recruitment advertising. Dijelaskan pula dalam Kriyantono (2008:178), bahwa dalam melakukan aktivitasnya, seorang praktisi public relatios sering kali menggunakan strategi periklanan. Hal ini digunakan sebagai alat dalam menjaga hubungan baik antar perusahaan dengan publiknya.

Danandjaja (2011:138) menjelaskan dalam bukunya yang berjudul "Peranan Humas dalam Perusahaan", bahwa Public Relations advertising lebih mengutamakan citra produk (brand image) dalam pembangunannya daripada sekedar menjual poduk, sehingga produk tersebut dapat dikenal dan bahkan menumbuhkan suatu fanatisme produk pada diri konsumennya. Public relations advertising juga berusaha memberikan suatu layanan informasi terkait kegunaan maupun kekhasan dari suatu produk, Public Relations advertising juga memperkenalkan produk tersebut agar menarik perhatian, sesuai daya jangkau publik dan kebutuhannya.

Di dalam Public Relations advertising, terdapat ciriciri khas seperti tidak menjual produk secara langsung melainkan melakukan soft selling, iklan soft selling inilah yang memiliki fokus dalam kesan umum (image) yang hendak diraih dalam menjual citra korporat (corporate image selling) yang memang pada tujuan akhirnya demi meraih keuntungan, penanaman citra korporat yang positif pun dilakukan. Praktisi Public Relations menggunakan iklan untuk beberapa bentuk kegiatan:

\section{Cantik: Wajah natural sebagai gagasan me- ngenai kecantikan perempuan}

Sejak awal 1900an, makeup sudah ada dan meramaikan standar kecantikan, terutama bagi kaum perempuan yang ingin tampak cantik. Seperti yang dapat dilihat pada salah satu video YouTube yang berjudul "100 years of eye makeup with Kandee Johnson" oleh Allure, makeup sudah menjadi salah satu faktor yang membuat perempuan menjadi cantik, terutama makeup pada bagian mata, perempuan pada awal tahun 1900an akan menggunakan warna-warna seperti abu-abu dan hitam disekitar mata mereka untuk menambah efek tajam dan tebal pada area mata. Pada tahun 2005an, smokey eye yang berarti efek asap pada mata juga sempat menjadi trend hingga akhirnya pada tahun 2016 ke 2017, keluarga Kardashians membawa pengaruh baru pada trend dalam fashion dan juga kecantikan seperti trend bulu mata palsu dan countour wajah yang tajam tanpa menggunakan eyeshadow lagi, hal-hal tersebut, seperti yang diperlihatkan pada sebuah video YouTube yang di rilis oleh TheTalko yang berjudul "10 Crazy Beauty and Fashion Trends Started by The Kardashians".

\section{Kecantikan Perempuan dalam Iklan}

Kecantikan merupakan benteng pertahanan milik perempuan, kondisi ini membuat pemasaran ke perempuan selalu digambarkan lewat stereotype yang muncul pada iklan produk yang dimainkan oleh perempuan dan secara tegas iklan membentuk konsep kecantikan tertentu bagi perempuan lewat iklan tersebut. Semua ini menjelaskan bahwa iklan yang disampaikan oleh media massa berperan penting dalam membentuk konsep kecantikan (Winami, 2010:135-136).

Tidak asing lagi jika melihat perempuan sebagai bintang iklan, karena perempuan dianggap memiliki suatu nilai yang dapat menarik perhatian banyak orang baik dari segi wajah, tubuh, pakaian dan gerakkan. Ibrahim dalam Aprilia (2005:50), menjelaskan bahwa sebagian besar iklan menggunakan perempuan sebagai modelnya. Kira-kira $90 \%$ periklanan menggunakan perempuan sebagai modelnya. Ada banyak alasan dalam menjadikan perempuan sebagai model iklan, salah satunya adalah untuk memperkuat daya jual produk. Perempuan dijadikan wadah promosi dari barang produksi dan produsen. Sisi erotisme dari tubuh perempuan pun bisa digunakan sebagai stopping power, yang memiliki arti adanya kekuatan yang digunakan dalam menghentikan orang untuk memperhatikan iklan yang ada pada majalah, koran, TV, spanduk, billboard dan sebagainya. Kekuatan tersebut dapat berasal dari warna, suara, pencahayaan, maupun model yang dipakai dalam iklannya.

\section{Audience Aktif sebagai Subyek Penelitian}

Menurut Dennis McQuail (1997) ada banyak versi dalam pengertian audience. Pengertian yang pertama, melihat audience sebagai populasi yang besar jumlahnya dan bisa dibentuk oleh media. Sedangkan yang kedua, menganggap audience sebagai anggota dalam kelompok-kelompok kecil yang berbeda-beda, yang sebagian besar dapat dipengaruhi oleh kelompoknya.

\section{Reception Analysis sebagai Metode Peneliti- an}

Khalayak, dijelaskan oleh Pujileksono (2016: 165166), dapat memanfaatkan media untuk mendapat 
suatu informasi, pendidikan, dan hiburan, oleh karenanya, khalayak tersebut disebut sebagai penonton. Khalayak sudah tidak pasif lagi, tapi menjadi aktif dalam perkembangannya. Mulai dari akhir memahami, memaknai, dan mengkonstruksi pesan yang dibaca, didengar dan ditontonnya. Kebenaran dari pesan menjadi tidak lagi tunggal, variatif dan subjektif. Dalam kajian relasi penonton atau khalayak dengan media massa, dapat menggunakan metode reception analysis.

\section{METODE}

Pendekatan yang digunakan pada penelitian ini adalah pendekatan kualitatif. Dalam hal ini, pendekatan kualitatif digunakan untuk menghasilkan data deskriptif berupa kata-kata tertulis atau lisan dari penonton yang telah menonton iklan SK II "Bare Skin Project". Pendekatan yang digunakan pada penelitian ini adalah pendekatan kualitatif.

Penelitian menggunakan jenis penelitian deksriptif, menggunakan data seperti kata-kata, gambar dan bukan angka-angka. Dikarenakan penggunaan pendekatan kualitatif. Oleh karenanya, laporan penelitian akan berisi kutipan data dalam memberi gambaran penyajian laporan tersebut. Data didapatkan dari naskah wawancara, catatan dilapangan, diskusi kelompok atau FGD, maupun angket (Pujileksono, 2016: 120).

Dalam penelitian ini, metode yang digunakan adalah reception analysis dengan paradigma encodingdecoding. Reception Analysis adalah cabang studi budaya modern tentang riset audiens yang secara kuat menegaskan pada peran "pembaca" dalam proses “decoding" dari teks media (McQuail, 1997:19).

Subjek penelitian ini adalah penonton perempuan yang merupakan target audiens utama dari iklan dan produk SK II seperti yang dijelaskan pada laman resmi milik SK II bahwa produk mereka adalah produk perawatan kulit bagi perempuan di seluruh duniadan iklan SK II "Bare Skin Project". Subjek dalam penelitian ini memiliki gender (perempuan), usia (diatas 22 tahun), pendidikan (minimal sarjana), dan jenis skincare. Sedangkan obyek penelitian adalah penerimaan perempuan mengenai kecantikan. Kriteria informan berdasarkan gender yaitu perempuan dikarenakan konsep kecantikan yang ingin diteliti adalah produk kecantikan perempuan. Unit analisis dalam penelitian ini adalah individu yang akan diamati hasil transkrip wawancaranya yang telah dilakukan oleh peneliti.
Untuk pengumpulan data akan dilakukan FGD (Focus Group Discussion) kepada informan yang telah dipilih. Kemudian peneliti menggunakan teknik analisis yang ditawarkan oleh Miles dan Huberman (1994) yaitu terdiri dari tiga komponen: reduksi data atau data reduction, penyajian data atau data display, dan penarikan serta pengujian kesimpulan atau drawing and verifying conclusions. Pada reduksi data, data yang dibuang bukan asal, melainkan usaha yang dilakukan peneliti selama analisis data untuk dilakukan dan menjadi langkah yang tak terpisahkan dari analisis data (Pawito, 2007: 104).

Melalui tahap penarikan dan pengujian kesimpulan ini, peneliti mulai menarik hasil temuan dan melakukan pengujian kesimpulan menggunakan tiga jenis penerimaan pesan yang diterima khalayak menggunakan paradigma encoding-decoding milik Struart Hall, (Hall, 2005: 125-127) yakni: Dominated Code, Negotiated Code dan Oppositional Code.

\section{PEMBAHASAN}

Data akan diperoleh berdasarkan hasil focused group discussion kepada 5 orang yang telah dipilih untuk menjadi informan. Subjek dalam penelitian ini perempuan dengan usia di atas 22 tahun, dengan latar belakang pendidikan, pekerjaan dan skincare yang berbeda.

Peneliti mendapatkan 5 orang subjek yang terdiri dari 5 orang perempuan yang memiliki usia 22 tahun, 23 tahun, 26 tahun, 26 tahun dan 28 tahun. Masingmasing subjek memiliki latar belakang pendidikan, pekerjaan serta skincare berbeda sehingga memiliki keberaragaman. FGD akan dilakukan pada lokasi dan waktu bersamaan yang akan ditentukan oleh subjek penelitian dan peneliti.

SubJek yang diambil oleh peneliti yakni: Intan Tito, usia 23 tahun, pekerjaan influencer, S1 Universitas Ciputra Surabaya, pengguna SK II. Devi Anggita Putri, usia 28 tahun, S1 Stikosa-AWS, pekerjaan MUA, pengguna USA products. Henny S. atau Mey, usia 26 tahun, S1 Universitas Petra Surabaya, pekerjaan swasta, pengguna produk Korea. Yessyca Neyra, usia 26 tahun, S1 UPN Jawa Timur, pekerjaan penjahit kostum, pengguna produk lokal. Naomi Mutiara Jasmine, usia 22 tahun, S1 UNAIR, pekerjaan cosplayer, pengguna produk dokter Natasha.

FGD akan dilakukan di Café Doho 22 yang berlokasi di jalan Dinoyo, lebih tepatnya pada pukul 18.00 WIB, waktu dan tempat dipilih karena sesuai dengan 
seluruh informan dan juga peneliti serta tim dari FGD nanti. peneliti membagi topik hasil interpretasi informan kedalam 4 sub-bab yakni (1) Keinginan untuk cantik alami, (2) Bangga dengan kulit wajah alami tanpa makeup, (3) Penggunaan skincare pada kecantikan perempuan, (4) Ideal cantik alami pada iklan.

\subsection{Keinginan Untuk Cantik Alami}

Pada iklan SK II "Bare Skin Project" yang berdurasi 1 menit 8 detik, terdapat voice over yang mengatakan bahwa "All of us have the chance to show our natural beauty". Dikatakan dengan jelas lewat salah satu scenenya bahwa setiap perempuan kini dapat memiliki kesempatan yang sama untuk menjadi cantik alami, yakni dengan tetap menggunakan produk SK II secara tidak langsung.

Pada hasil wawancara FGD.Menurut Intan, Mey dan Yesi, cantik alami tidak ada, sebab kecantikan itu didapat melalui bagaimana seseorang merawat dirinya sendiri. Menurut Intan, apabila orang tersebut merawat dirinya dengan baik maka orang tersebut baru dapat disebut cantik. Sebaliknya, apabila tidak dirawat dengan baik, maka orang tersebut dibilang jorok dan dalam menjadi cantik, Intan menyatakan hal tersebut seperti pembawaan diri yang tidak hanya datang lewat penggunaan skincare, namun juga pola makan, sehingga tidak hanya lewat penggunaan skincare namun juga kebersihan diri.

"Orang kan kalau cantik ya cantik tapi kalau jorok ya cantiknya berkurang kalau kita nggak ngerawat, jadi kalau bener emang cantik alami itu nggak ada (Intan Tito, 23 tahun)".

Oleh karena itu jugalah, Intan juga merupakan seseorang yang sering merawat dirinya juga lewat berbagai macam perawatan. Bahkan juga datang ke dokter kecantikan untuk mempercantikan kulit wajahnya. Misalnya melakukan eyelash extension hingga sulam alis. Baginya semua itu tidak apa-apa karena terhitung sebagai merawat diri untuk tetap jadi cantik.

Sementara menurut Mey, cantik alami didapat dari kesungguhan merawat wajah, perlu perhatian lebih juga agar terlihat lebih bagus dan indah. Tanpa merawat diri tidak akan terlihat cantik tersebut pada diri seseorang. Misalnya dengan rajin menggunakan masker wajah seperti dicontohkan oleh artis-artis diluar sana.

"Cantik alami itu diawali dari merawat, sesuatu yang dirawat akan terlihat lebih bagus dan indah, untuk merawatnya pun butuh perhatian lebih, jadi kalau untuk cantik yang bener-bener alami tanpa merawat sih ya nggak ada. Misalnya rajin pakai masker wajah, kan lagi trend tuh, kayak artis-artis kecantikan diluar sana kan gitu, mereka juga jadi panutan buat aku dalam ngerawat wajahku (Mey, 26 tahun)".

Sehingga sesuai dengan apa yang dijelaskan pada jurnal Rita (2013: 158) yang menyatakan bahwa Vicarious role model atau role model ialah orangorang yang akhirnya dikenal dikarena akan kemampuannya pada suatu bidang tertentu, para role model inilah yang sering kali membawa trend kecantikan seiring berjalannya waktu. Seperti yang dikatakan oleh Mey yang akhirnya menjadikan role model tersebut panutannya dalam menjadi cantik. Kemudian menurut Yesi cantik alami merupakan sesuatu yang muncul setelah menjaga wajah, bukan hal yang didapat tanpa adanya proses perawatan wajah. Misalnya, ketika seseorang memiliki kulit wajah berminyak namun tidak dirawat maka cantiknya akan hilang.

"Nggak, cantik alami itu sesuatu yang muncul kalau kita jaga. Jadi kalo nggak, ya nggak akan dapet itu cantik alaminya. Misalnya uda tau mukanya berminyak tapi dibiarin nggak dirawat, ya hilang cantiknya.Jadi mesti dijaga terus menerus kalau mau bertahan lama haha (Yesi, 26 tahun)".

Sehingga Yesi berteguh dengan pernyataannya yakni cantik alami itu tidak ada tanpa adanya perawatan diri. Lain halnya dengan Naomi dan Devi, menurut Naomi cantik merupakan hal yang subjektif, yakni berdasarkan pandangan orang lain. Naomi meneruskan walau seseorang tidak merawat diri dengan baik, apabila orang tersebut sudah cantik, orang tersebut tetap dilihat cantik meskipun ia jorok.

"Cantik alami sebenernya subjektif, tapi gimana orang lain melihat juga sih. Orang jorok pun bisa lihat cantik kan beda yah aha. Cantik alami itu susah. juga sih sebenernya hehe, cantik itu dengan caranya sendiri, gimana cara mereka enhance itu. Jadi emang susah sih biar dianggep cantik (Naomi, 22 tahun)".

Bagi Naomi hal tersebut juga sesuai dengan pengalamannya dalam menganggap seseorang cantik baginya namun juga belum tentu hal tersebut sama dengan orang lain. Sebuah perspektif yang Naomi berusaha berikan melihat bagaimana seorang perempuan dapat dikatakan cantik tidaknya, ia yang belajar psikologi berusaha menjabarkan pemikirannya akan bahasan kecantikan. 
Sementara menurut Devi, cantik alami itu tidak ada dan bukan berdasarkan dari bagaimana seseorang merawat dirinya, melainkan cantik alami adalah hal yang dapat dicapai lewat penggunaan skincare serta makeup juga.

"Cantik alami itu nggak ada, karena harus tetep pakai skincare berapapun harganya, juga ya biasanya tetep harus makeup juga. Nggak munafik ya, jaman sekarang nggak ada perempuan yang bener-bener bare face apalagi yang mau atau bisa dibilang cantik, minimal mereka pasti ada perawatan dan kalau keluar rumah ya pakai makeup walau tipis misalnya pakai alis atau lipstick lah, atau kalau nggak ya bedak wes (Devi, 28 tahun)".

Devi pun menyatakan bahwa pada jaman sekarang tidak ada perempuan yang benar dapat bare face yang mau atau dapat dikatakan cantik, menurutnya perempuan tersebut pasti tetap menggunakan skincare atau bahkan minimal menggunakan makeup walau hanya keluar numah. Bisa jadi penggunaan alis atau lipstick serta bedak menurut Devi menjadi suatu patokan minimal dalam seorang perempuan. Apalagi makeup menurut Devi juga sudah menjadi hal yang sangat normal untuk ada dan digunakan oleh perempuan, berbeda dengan dahulu yang mungkin tidak semua perempuan mau atau menggunakan makeup apalagi jika hanya keluar rumah dan tidak bepergian jauh.

Oleh karena itu, peneliti mengelompokkan jawaban dari keempat informan kedalam posisi oppositional code karena menolak dan mengambil makna pesan yang berlawanan daripada apa yang ditampilkan oleh SK II "Bare Skin Project", keempat informan yakni Intan, Mey, Devi, dan Yessi menyatakan bahwa tidak ada kecantikan yang alami, semua harus dicapai lewat penggunaan skincare atau bahkan penambahkan lewat makeup terlebih dahulu untuk dapat tampil cantik. Baik penggunaan makeup tipis seperti bedak, alis, lipstick juga dalam pengaplikasian skincare, bisa juga dalam melakukan perawatan diri seperti menggunakan masker wajah.

Sementara, Naomi justru mengatakan hal yang berbeda, karena menurutnya cantik merupakan suatu hal yang subjektif dan dapat dipandang berbeda tergantung siapa yang melihat, namun ia tetap tidak memungkiri bahwa cantik alami itu hal yang susah dicapai juga, oleh karenanya peneliti mengelompokkan Naomi kedalam posisi negotiated code karena informan tidak sepenuhnya menerima pesan cantik alami menurut SK II "Bare Skin Project". Ada hal yang Naomi dapat terima dalam hal memandang cantik itu sendiri namun tidak sepenuhnya sesuai dengan yang dimaksud oleh SK II "Bare Skin Project".

\subsection{Bangga Dengan Kulit Wajah Alami Tanpa Makeup}

Pada scene dalam iklan juga muncul gambar wajah model yaitu Chloe Moretz yang menunjukkan dirinya yang tampil bangga dihadapan banyak orang tanpa menggunakan makeup. Hal ini juga merupakan pesan besar yang ingin diberikan oleh SK II menurut peneliti, menanamkan sudut pandang baru dan berbeda pada perempuan bahwa mereka dapat bangga dengan kulit wajah alami tanpa makeup. Berdasarkan gambar tersebut peneliti ingin melihat bagaimana penerimaan oleh informan terhadap pesan bangga dengan kulit wajah yang alami tanpa menggunakan makeup seperti yang ditunjukkan oleh SK II "Bare Skin Project".

Berdasarkan jawaban dari kelima informan, semua informan mengeluarkan pernyataan yang sama terkait adanya peningkatan kepercayaan diri oleh karena makeup, namun dengan sudut pandang yang berbeda. Intan mengatakan bahwa makeup sudah menjadi bagian darinya yang membantunya untuk menaikkan kepercayaan diri serta harga dirinya, ditambah dengan penggunaan produk-produk yang mahal yang menjadikannya sebagai nilai plus dalam penggunaan makeup tersebut, produk yang ia gunakan seperti makeup dengan merek mahal ternama seperti MAC serta Jaclyn Hill, koleksi yang ia miliki pun juga cukup banyak. Ia pun bangga dengan kulit wajahnya saat ini terlepas dari penggunaan makeup tersebut dikarenakan penggunaan skincare yang menurutnya sudah sangat cukup bagus. Walaupun tidak dapat dipungkiri juga Intan juga sudah melakukan berbagai macam prosedur perawatan kecantikan seperti sulam alis serta eyelash extension guna mempercantik kulit wajahnya, mengingat ia juga bekerja sebagai influencer yang tentunya akan menjadi panutan banyak orang yang menghadiri event Intan.

"Makeup itu uda jadi bagian dari aku sih ya buat menaikkan kepercayaan diri dan harga diri, misal lagi kumpul highlighter centrongkan apalagi mahal itu jadi nilai plus pastinya (Intan Tito, 23 tahun)".

Intan juga seringkali ditanyai oleh berbagai macam kawan serta orang-orang yang menghadiri event-nya, terkait dengan produk yang ia gunakan, oleh karenanya menjadi penting bagi Intan untuk tetap membeli dan menggunakan produk makeup yang 
mahal. Terlepas dari fungsi dan kegunaannya, itulah nilai plus yang dimaksud oleh Intan.

Sementara itu, Mey dan Yessi lebih melihat makeup sebagai suatu penambahan daripada kecantikan itu sendiri, yang berarti selain menambah kepercayaan diri juga meningkatkan hasil cantik itu sendiri. Misalnya Mey yang dulu pernah tinggal di Korea beberapa tahun pun menyebutkan betapa pentingnya makeup disana terutama pada lingkungan bekerja setiap harinya. Ia yang juga sempat bekerja di Korea pun bercerita bagaimana ia disana diharuskan untuk setiap hari tetap tampil rapi serta menggunakan makeup dalam bekerja, kalau tidak akan diingatkan oleh rekan kerja atau atasannya disana dikarenakan terkesan tidak siap atau rapi. Seperti dikutip dari metro.co.uk, sosiolog Jaclyn Wong dan Andrew Penner mengumpulkan data dari sedikitnya 14.000 karyawan untuk mencari tahu kaitan antara gaji/ pendapatan dan usaha mereka untuk dandan dan memang benar makeup menjadi salah satuk faktor penting bagi penerimaan pekerja-pekerja tersebut, sama halnya seperti yang dikatakan oleh Mey. Mereka menemukan bahwa perempuan yang dandan di tempat kerja digaji lebih banyak dibandingkan perempuan yang tidak dandan.

"Gini, di Korea, orang itu harus pakai makeup, setiap hari. Karena dulu aku pernah di Korea cukup lama juga ya. Kalau kerja ga pake makeup bisa habis aku, nah makeup itu cara enhance kecantikan kita, selain penting ya menurut aku, makeup juga menambah kepercayaan diri seorang perempuan lah. Jadi sudah jadi satu kesatuan juga (Mey, 26 tahun)".

Namun tidak hanya untuk bekerja, menggunakan makeup juga sudah menjadi suatu hal yang akan menambahkan kepercayaan diri seorang perempuan juga, suatu kesatuan. Bepergian di Korea baik jauh maupun dekat, menggunakan makeup sudah menjadi hal yang biasa. Setipis apapun makeup tersebut, misalnya menggunakan lipstick atau blush on saja.

Sementara itu, Yesi juga menyebutkan contoh daripada penambahan makeup untuk menjadi cantik misalnya menutup wajah minyakan dengan bedak. Yesi juga menyatakan bahwa penambahan yang dilakukan disini dapat digunakan untuk mengisi bagian yang kurang misalnya menggunakan eyeshadow pada mata untuk mempertambah kecantikan itu sendiri.

"Makeup itu tambahan dari kecantikan itu sendiri, kita udah usaha tapi kulit tetep minyakan misalnya, nah ada makeupnya tuh si bedak kan. Makeup itu tambahan deh. Selain untuk kerja juga, kalau pas kita ngerasa kita kurang dibagian mana misalnya mata, ya ditambah deh misal pakai eyeshadow, jadi cantiknya nambah karena bantuan makeup itu (Yesi, 26 tahun).”

Dengan adanya makeup, perempuan kini dapat terbantu dalam pencapaian hasil kulit wajah cantik yang mereka mau. Tidak hanya untuk bekerja, menurut Yessi. Semua kekurangan perempuan dapat ditutupi atau ditambahkan kecantikannya lewat penggunaan makeup tersebut.

Keduanya juga menyatakan bahwa mereka kurang bangga pada kulit wajahnya apabila tidak menggunakan makeup. Dapat dikatakan juga bahwa makeup telah menjadi bagian dari hidup mereka dengan menjadikan makeup sebagai penambahan kecantikan.

Naomi di sisi lain menyatakan bahwa makeup itu seperti dekorasi yang membuat seseorang dapat tampil lebih pede dalam mengekspresikan diri namun bukan menjadi sesuatu yang penting dalam dirinya, ia pun sangat bangga dengan kulit wajahnya tanpa makeup dikarenakan perawatan dari dokternya yang ia claim aman dan hasilnya kelihatan. Meskipun sehari-hari ia dituntut juga harus menggunakan makeup ketika bekerja menjadi cosplayer.

"Makeup itu dekorasi, tapi dari semua dekorasi yang kita pakai itu bisa buat kita makin pede dan juga makeup bisa jadi cara untuk mengekspresikan diri, Cuma tetep bukan hal yang penting sih ya kalau buat aku, aku pakai makeup tetep ketika memang diperluin aja misal pas ngejob kan ya cosplay pasti pakai makeup, dah gitu macem-macem juga makeupnya ganti-ganti (Naomi, 22 tahun)".

Walau begitu, apa yang dikatakan oleh Naomi akhirnya sangat berbanding terbalik dengan kenyataan bahwa Naomi masih membutuhkan makeup dan secara tidak langsung makeup menjadi penting bagi hidup Naomi, secara pekerjaan dan pembentukan identitasnya sebagai seorang cosplayer handal juga. Bahwa tanpa makeup, Naomi mungkin tidak akan menjadi dirinya yang sekarang ini, meskipun dengan segala penggunaan skincare dokter yang ia gunakan.

Sementara itu bagi Devi yang menyatakan bahwa makeup merupakan suatu hal yang sangat penting dihidupnya, makeup tidak hanya untuk tampil pede namun juga dapat memunculkan power serta respect meskipun penggunaan makeup yang tipis. Dengan menggunakan makeup, ia dapat beroleh rasa hormat 
serta kuasa akan orang-orang yang sedar bersama dia atau ada disekitarnya secara sadar maupun tidak sadar.

"Makeup itu penting banget dihidupku, selain bikin pede ya. Bahkan dengan makeup seharihari aja itu bisa membuat orang jadi punya power karena mereka bisa percaya diri walau makeup yang tipis-tipis, dapet respect juga lah. Aku juga karena biasanya kerja jadi MUA, otomatis makeup ya jadi hal wajib di aku, masa klien minta aku makeup-in tapi tampilanku ternyata lebih buruk daripada klienku sendiri, bisa-bisa kredibilitasku yang dipertanyakan kalau kayak gitu. Jadi memang selain untuk bikin tambah cantik ya itu wes kayak bagian hidupku lah (Devi, 28 tahun)".

Terlebih lagi Devi sehari-hari bekerja sebagai MUA (Makeup Artist) yang akhirnya membuat dirinya harus tampil cantik dan tidak mengecewakan kliennya dengan cara menggunakan makeup yang bagus juga, yakni untuk Devi ialah produk dengan merek-merek USA. Devi juga menyatakan bahwa makeup sudah menjadi bagian dari hidupnya. Manusia kini menjadi makhluk yang selalu menuntut halhal baru yang semakin baik, sehingga mereka kurang suka pada kosmetika yang hanya menghias kulit tapi tidak memberikan perbaikan pada kulit (Tranggono: 1996: 28). Sehingga Devi pun menyatakan bahwa dirinya tidak bangga dan percaya diri apabila tidak menggunakan makeup sama sekali. Bahkan terlepas dari pekerjaannya sebagai MUA, ia juga merasa memperlukan makeup untuk tampil dihadapan publik pada sehari-harinya.

Dari jawaban yang diberikan oleh kelima informan, peneliti mengelompokkan jawaban definisi makeup yang dirasakan oleh kelima informan kedalam opossitional code karena menurut kelima informan, makeup tetap merupakan sesuatu yang penting pada perempuan dan dapat meningkatkan baik kepercayaan diri serta kecantikan mereka, tidak sesuai dengan iklan SK II Bare Skin Project yang melihat makeup sebagai hal yang tidak perlu lagi digunakan oleh perempuan untuk terlihat cantik.

\subsection{Penggunaan Skincare Pada Kecantikan Perempuan}

Pada scene yang ada pada SK II "Bare Skin Project" terdapat kalimat "I've been using Facial Treatment Essense for weeks now" dan dilanjut dengan "and I can feel it helping my skin". Berdasarkan kalimat tersebut peneliti ingin melihat penerimaan oleh informan terhadap akan penggunaan skincare tertentu pada kecantikan perempuan, dan dalam hal ini pada iklan produk skincare yang digunakan yakni SK II Facial Treatment Eessense.

Berdasarkan jawaban keempa tinforman yang telah mengikuti FGD oleh peneliti yakni Mey, Yessi, Devi dan Naomi, semuanya sepakat bahwa skincare yang mereka gunakan sudah cukup dan lebih memberikan hasil daripada skincare yang ditawarkan oleh SK II yaitu Facial Treatment Essense, meskipun sudah dinyatakan oleh SK II produk tersebut dapat membantu kecantikan kulit wajah, dan dapat membuat perempuan tampil cantik tanpa menggunakan makeup.

Menurut Mey, produk dari Korea lebih bagus karena menurut pengalamannya hasil finishing daripada produk Korea lebih neutral daripada produk makeup lainnya, secara skincare sendiri juga Mey menyatakan bahwa skincare dari Korea lebih cocok dikulitnya hingga sekarang ia pun menyatakan dengan percaya diri bahwa kulitnya masih cantik glowing berkat produk-produk Korea tersebut.

"Kalau aku sih karena aku lebih suka pakai produk Korea ya aku memang lebih suka karena finishing-nya lebih natural daripada yang produk-produk lainnya kalau makeup, skincarenya juga lebih ngefek sih di aku. Jadi aku pede aja ya, masih kelihatan cantik glowingkan aku ya karena pakai produk Korea haha (Mey, 26 tahun)".

Bagi Mey, skincare yang ia gunakan sudah cukup membuat kulit wajah perempuan terlihat cantik bening glowing seperti tidak menggunakan makeup, jadi tidak perlu juga baginya menggunakan produk lain lagi.

Sementara itu, Yesi juga menceritakan bahwa dirinya sudah lama menggunakan produk lokal dan cocok dengan wajahnya hingga sekarang sehingga secara tidak sadar juga hal tersebut membuatnya takut mencoba hal-hal baru. Meskipun kulit wajah Yesi jarang jerawatan juga. Produk skincare lokal yang Yesi gunakan biasanya seperti milik Viva, terutama pembersih mukanya sejak dulu ia masih menjadi cosplayer hingga kini bekerja menjadi costume maker.

"Aku sudah lama pakai produk lokal dan cocok dimuka aku sih jadi nyaman aja sampai sekarang, mukaku juga soalnya jarang jerawatan. Jadinya kalau menurut aku bukan masalah merek, harga dan apalah lagi lah, tapi cocok 
nggak nya itu lho, kalau uda cocok yawis aman (Yesi, 26 tahun)".

Yesi juga menyebutkan bahwa produk lokal ia pilih bukan karena harganya yang murah namun juga setelah berbagai diskusi ia lakukan serta pencarian akan merek baru tersebut baru Yesi akan mungkin tertarik mencoba makeup tersebut. Karena meskipun kini ia bekerja sebagai costume maker. Tak dapat dipungkiri juga bahwa Yesi pernah beberapa kali manggung dengan makeup bermacam-macam juga sebagai seorang cosplayer. Sehingga ketika ia kini merasa cocok dengan produk lokal, ia tidak harus lagi menggunakan produk lainnya yang mungkin lebih mahal dari yang ia gunakan.

Sementara Devi lebih memilih menggunakan produkproduk kecantikan merek dari western dikarenakan selain cocok, Devi yang bekerja sebagai MUA juga ingin dilihat lebih kredibel dalam bidangnya serta hobinya dalam review produk kecantikan.

"Aku orangnya soalnya selain dituntut punya banyak makeup, buat jaga kredibilitas ye, aku juga memang suka review produk juga dan ya aku pilih kebanyakan produk kecantikan aku dari western karena cocok dan menurut aku terbaik sih di wajah aku (Devi, 28 tahun)".

Karena juga menurut Devi, banyak dari klien yang memilihnya dikarenakan oleh pilihan produk yang ia gunakan dan beli, produk dari western seperti merek MAC, Estee Lauder dan juga berbagai macam produk skincare asal western juga seperti milik Jeffree Star. Banyak klien juga menanyakan produkproduk yang Devi digunakan karena Devi sering mereview produk-produk tersebut. Hal tersebut juga menjadikannya mengoleksi begitu banyak produk skincare juga.

Kemudian apabila menurut Naomi, produk-produk skincare yang ia gunakan yakni dari dokter Natasha, sudah cocok dan nyaman digunakannya hingga sekarang. Kulit wajah Naomi yang harus sering menggunakan makeup dikarenakan pekerjaannya sebagai cosplayer.

"Aku juga karena sudah cocok dan lama pakai perawatan dari dokter jadi sampai sekarang masih memilih tetep pakai produk dokter. Apabila aku bakal sering banget pakai makeup jadi otomatis produk dokter itu yang bakal nyelametin aku hehe (Naomi, 22 tahun)".

Dalam melakukan pekerjaannya, Naomi diharuskan untuk selalu menggunakan berbagai macam makeup yang tentunya akan membuat kulit wajahnya menjadi sering terpapar bahan kimia yang ada pada produkproduk makeup tersebut. Oleh karenanya produk dokter yang sudah ia gunakan tersebut sudah cocok dan nyaman bagi Naomi, terbukti hingga sekarang kulit wajah Naomi jarang mengalami jerawatan dan bahkan terlihat cerah.

Intan disini sebagai salah satunya informan yang sangat setuju dengan apa yang SK claim, bukan hanya karena ia menggunakan produk SK II tapi juga menurutnya skincare SK II FTE itu sangat memiliki dampak baginya dalam mempercantik wajahnya sehingga ia pun pede tidak menggunakan makeup juga.

"Ya, karena selama ini ngefek ya di wajah aku terutama merek-merek yang mahal kayak SK II, hasilnya juga kelihatan aja sih sampai sekarang juga ga pernah yang kusam atau jerawatan. Apalagi produk FTE nya itu siapa ya yang gatau, karena pakai SK II juga aku kalau ga pake makeup ya pede pede aja. Hari ini aja aku kesini ga pake makeup kan" (Intan Tito, 23 tahun).

Melihat dari jawaban kelima informan, maka peneliti dapat melihat adanya dua posisi berbeda. Dalam hal ini ada empat informan yang masuk kedalam posisi oppositional code. Keempat informan tersebut yakni Mey, Devi, Yessi dan Naomi belum menerima pesan yang diberikan oleh iklan SK II "Bare Skin Project". Dalam hal ini pemaknaan yang ditolak oleh informan yaitu mengenai pernyataan SK II akan ajakannya dalam menggunakan produk SK II yakni Facial Treatment Essense yang dapat membuat kulit wajah menjadi cantik tanpa menggunakan makeup. Hal ini karena semua informan memiliki pengalaman bahwa tidak semua perempuan harus menggunakan skincare tersebut dalam menjadi cantik, Sementara satu informan yakni Intan yang masuk kedalam posisi dominant, karena menerima pesan yang diberikan oleh iklan SK II "Bare Skin Project". Dalam hal ini pemaknaan tersebut juga diterima Intan karena selama ini memang Intan sudah lama menggunakan dan cocok dengan skincare dari SK II.

\subsection{Ideal Cantik Alami pada Iklan}

Pada sub-bab ini, peneliti ingin menjabarkan bagaimana penerimaan dari kelima informan berdasarkan frame of reference dan field of experience yang dimiliki masing-masing informan. Berdasarkan hasil wawancara FGD yang didapatkan oleh peneliti, para informan memang mengatakan bahwa mereka tidak setuju bahwa cantik alami itu ada, namun ketika 
peneliti telusuri lebih dalam lagi. Dari kelima informan tersebut, peneliti mendapati empat orang yang masuk kedalam posisi oppositional karena menolak pesan yang disampaikan oleh SK II "Bare Skin Project".

Sementara satu informan tetap teguh dengan jawabannya selama FGD walau terkadang sering disanggah oleh informan lain, satu informan ini awalnya bisa dikategorikan kedalam posisi dominant karena menerima pesan yang disampaikan oleh SK II "Bare Skin Project". Namun informan tersebut juga tidak menolak penggunaan makeup dan kegunaannya yang juga sudah menjadi pelengkap dalam perempuan untuk menjadi cantik sehingga menjadikannya dapat masuk kedalam posisi negotiated code karena menerima pesan yang disampaikan SK II "Bare Skin Project" namun juga dengan kondisi tertentu. Selain itu, apabila dilihat kembali latar belakang dari para informan. Keempat informan yang menolak pesan SK II juga dikarenakan keempat informan tersebut adalah konsumen atau pengguna dari berbagai macam jenis produk skincare atau makeup diluar SK II.

Pada akhirnya konsep atau kata "cantik" memiliki definisi yang sangat sempit dimasyarakat kita, meskipun sebagian orang mengatakan bahwa cantik itu relative namun kebanyakan mengatakan bahwa "cantik" definisinya adalah yang memiliki wajah mulus dengan menggunakan makeup, mematahkan mitos kecantikan lewat buku mengenai mitos kecantikan milik Wolf, muncul sebuah pernyataan akan hal ini: Kualitas yang disebut dengan "cantik" benarbenar ada, secara objektif dan universal (Wolf, 2004: 29). Kecantikan dipercaya merupakan konsep yang berlaku universal. Konsep kecantikan masa sekarang adalah berkulit putih, mulus, dan bebas jerawat, berbadan ramping dan tinggi, berambut lurus, dan lain sebagainya. Berdasarkan catatan jawa kuno, diketahui bahwa konsep kecantikan itu memiliki berbagai definisi. Dengan kata lain, kecantikan ada bermacammacam. Namun sekarang, kecantikan seakan tidak hanya sekedar mengenai kulit putih, mulus dan bebas jerawat, berbadan ramping dan tinggi serta lain sebagainya. Namun juga tampil cantik dengan menggunakan makeup.

Kemudian perusahaan tentunya melihat apa yang dinamakan oleh perilaku konsumen untuk mempengaruhi konsumen agar bersedia membeli barang dan jasa perusahaan lewat segala cara dan konsep iklan, seperti yang dilakukan oleh perusahaan SK II. Ditambah lagi dalam bukunya, Gassing (2016: 129130) menjelaskan bahwa demi mencapai tujuan organisasi atau disini perusahaan, praktisi PR juga harus turut serta dalam setiap prosesnya. Salah satu proses yang berkaitan dengan program kerja adalah promosi dan pemasaran untuk membantu PR bekerja, ada beragam alat yang dapat digunakan, diantaranya melalui iklan korporat yakni SK II "Bare Skin Project".

Tanpa disadari oleh masyarakat, keseluruhan iklan yang dibuat oleh perusahaan sebenamya adalah omong kosong belaka karena pada akhimya setiap orang yang menggunakan produknya atau tidak tetaplah perempuan yang dapat dikatakan cantik atau tidak, ditambah lagi perempuan yang hendak beroleh cantik tersebut diharuskan menggunakan produk unggulan mereka yakni Facial Treatment Essense. Para penonton dapat dikatakan sebagai perempuan yang cantik atau tidak dalam hal ini para informan yang diwawancari pada akhirnya akan tetap menggunakan produk unggulan mereka masing-masing. Media pun belum tentu bisa mengubah pemikiran akan standar kecantikan perempuan yang pada akhirnya juga kelima informan tetap mengakui bahwa keberadaan makeup bagi kecantikan seorang perempuan tetaplah harus ada dan tidak bisa dihilangkan.

\section{KESIMPULAN}

Penerimaan pada informan dalam penelitian ini dibagi menjadi empat sub-bab bagian, keinginan untuk cantik alami, bangga dengan kulit wajah alami tanpa makeup, penggunaan skincare pada kecantikan perempuan dan ideal cantik alami pada iklan.

Hasil dari FGD yang telah dilakukan, didapatkan hasil bahwa dari lima orang informan, empat diantarnya menolak isi pesan pada iklan SK II Bare Skin Project dan tidak menerima pesan dan makna pesan kecantikan yang terkandung didalamnya. Konsep kecantikan alami tanpa makeup yang ingin SK II ciptakan tidak bisa menjadi sebuah terobosan untuk mengubah standar kecantikan. Hal ini terlihat pada satu informan yang merupakan pengguna produk tersebut. Menurutnya makeup tetap menjadi bagian daripada standar kecantikan perempuan hingga sekarang.

Dan jika di lihat lebih dalam dari hasil FGD kepada kelima informan, berdasarkan frame of reference dan field of experience yang dimiliki masing-masing informan yakni dari produk apa saja yang mereka gunakan sehari-hari, juga lewat pekerjaan dari masing-masing informan, bagaimana para informan menilai seseorang yang dikatakan cantik. Posisi 
penerimaan keempat informan sama, yaitu berada dalam posisi oppositional karena keempat informan menggunakan berbagai macam produk kecantikan yang berbeda namun memiliki satu suara yang sama yang menolak isi pesan dan makna dari iklan SK II "Bare Skin Project", sementara satu orang informan berada pada negotiated dikarenakan informan tersebut menerima pesan dan pemaknaan yang diberikan oleh SK II namun menurutnya cantik itu tetap membutuhkan makeup dalam kesehariannya.

\section{DAFTAR PUSTAKA}

Abdullah, Ma'Ruf. 2017. Manajemen Komunikasi Periklanan.Yogyakarta: Aswaja Pressindo.

Adams, Jeans \& Breed, Maxine. 1975. Woman's Contemporary Image. New Jersey. PrenticeHall, Inc., Englewood Cliffs.

Ambara, Janice. (2014). Penerimaan Pemirsa Perempuan Terhadap Pesan Gaya Hidup Dalam Iklan-iklan Kopi Dengan Endorser Perempuan. Surabaya: Jurnal E-Komunikasi Program Studi Ilmu Komunikasi Universitas Kristen Petra. Vol.1, No.2.

Aprilia, Dwi Ratna. (2005). Iklan dan Budaya Popular: Pembentukan Identitas Ideologis Kecantikan Perempuan Oleh Iklan. Yogyakarta: Jurnal Ilmu Komunikasi Mahasiswa Program Studi Ilmu Komunikasi FISIP Angkatan 2002. 1(2) 41-68

Ariani, Meldina. (2015). Representasi Kecantikan Wanita Dalam Film "200 Pounds Beauty" Karya Kim Young Hwa. Kalimantan: eJournal Ilmu Komunikasi Universitas Mulawarman. 3(4): 320-332

Bungin, Burhan. 2015. Konstruksi Sosial Media Massa. Jakarta: Prenadamedia Group.

Ciptasetya, Amos Octa. (2018). Penerimaan Mahasiswa Mengenai Image Pt. Nutrifood Indonesia dalam Vlog Arief Muhammad "Kantor Nutrifood". Surabaya: Universitas Katolik Widya Mandala Surabaya.

Clinique, https://www.youtube.com/user/Clinique/ videos, diakses pada Agustus 2019

Dananjaja. 2011. Peranan Humas dalam Perusahaan. Yogyakarta: Graha Ilmu.

Fitryarini, Inda. (2009). Iklan dan Budaya Popular: Pembentukan Identitas Ideologis Kecantikan Perempuan Oleh Iklan Televisi. Samarinda: Jurnal Komunikasi Staf Pengajar Jurusan Ilmu Administrasi Program Studi Ilmu Komunikasi FISIP Universitas Mulawarman.Vol 6 No.2, $119-136$

Gassing, Syarifuddin S \& Suryanto. 2016. Public Relations. Yogyakarta: Andi Offset.
Gunawan, Metha. (2013). Penerimaan Penggemar SNSD Terhadap Kecantikan SNSD Dalam Video Klip GEE. Surabaya: Jurnal E-Komunikasi Program Studi Ilmu Komunikasi Universitas Kristen Petra. Vol 1 No.3

Hadi, Ido Prijana. (2008). Penelitian Khalayak Dalam Perspektif Reception Analysis. Surabaya: Jurnal Ilmiah SCRIPTURA, Universitas Kristen Petra. Vol 2, No.1 (1-7)

Hall, Stuart. 2005. Culture, Media, Languange. Newyork: Taylor \& Francis e-Library.

Jefkins, Frank. 1997. Periklanan. Jakarta: Erlangga.

Kiehl's Since 1851, https://www.youtube.com/user/ KiehlsNYC/videos, diakses pada Agustus 2019.

Kriyantono, Rachmat. 2008. Public Relations Writing. Jakarta: Prenada Media Group.

Kriyantono, Rachmat. 2017. Teori-Teori Public Relations Perspektif Barat \& Lokal: Aplikasi Penelitian Dan Praktik. Jakarta: PT Fajar Interpratama Mandiri.

Loccitane, https://www.youtube.com/user/loccitaneenprovence/videos, diakses pada Agustus 2019.

McQuail, Denis. 1997. Audience Analysis. London: Sage Publications.

Moerdijati, Sri. 2012. Buku Ajar Pengantar Ilmu Komunikasi. Surabaya: PT. Revka Petra Media.

Nayumi, Phelia. (2018). Penerimaan penonton mengenai kecantikan perempuan pada corporate advertising Clean \& Clear versi "1000 Suku Indonesia, Warna Kulit Berbeda”. Surabaya: Universitas Katolik Widya Mandala Surabaya.

Pawito. 2007. Penelitian Komunikasi Kualitatif. Yogyakarta: PT. LKiS Pelangi Aksara.

Perempuan yang memakai makeup saat bekerja, https://metro.co.uk/2018/06/06/women-wearmakeup-get-paid-work-7608932/, diakses pada Agustus 2019.

Piliang, Yasraf Amir. 2013. Hipersemiotika, Tafsir Cultural Studies Atas Matinya Makna. Yogyakarta: Jalasutra.

Priyatna, Aquarini. 2013. Becoming White, Representasi Ras, Kelas Feminitas dan Globalitas dalam iklan Sabun. Yogyakarta: Jalasutra.

Pujileksono, Sugeng. 2016. Metode Penelitian Котиnikasi Kualitatif. Malang: Kelompok Intrans Publishing.

Rita. (2013). Pengaruh Role Model's Influence Pada Materialism Dan Marketplace Knowledge Periode Remaja Akhir. Jakarta: Management Department, School of Business Management, BINUS University. Vol. 4 No.1, 157-169

SK II Bare Skin Project Chloe Moretz, https://www. youtube.com/watch? $v=u-h w Q k 5 l 9 g c$, diakses pada Agustus 2019 
SKII-Indonesia. https://www.youtube.com/user/indonesiaskii, diakses pada Agustus 2019.

Soekanto, Soerjono. 2017. Sosiologi: Suatu Pengantar. Jakarta: PT. Raja Grafindo Persada

Tranggono, Retno I.S. 1996. Kiat Apik Menjadi Sehat dan Cantik Petunjuk Praktis Perawatan Kulit dan Penggunaan Kosmetika bagi Kaum Muda. Jakarta: Gramedia Pustaka Utama.

Utomo, Vinson Vanda. (2017). Penerimaan Remaja Perokok Aktif mengenai bahaya merokok melalui iklan Korporat Kemenkes RI 2014-2016 di Televisi. Surabaya: Universitas Katolik Widya Mandala Surabaya.

Video 100 years Eye Makeup oleh Kandee Johnson, https://www.youtube.com/watch?v=97iptVO, diakses pada Agustus 2019.

Video Critics Choice Awards 2019, https://www. allure.com/gallery/critics-choice-awards-2019best-hair-makeup-looks, diakses pada Agustus 2019.
Video The Talko Kardashians, https://www.youtube. com/watch? $v=S 6 N Y \_l D n Y I O$, diakses pada Agustus 2019.

Vidyarini, Titi Nur. (2007). Representasi Kecantikan dalam Iklan Kosmetik The Face Shop. Surabaya: Jurnal Ilmiah SCRIPTURA Jurusan Ilmu Komunikasi. Vol. 1, No. 2, Universitas Kristen Petra.

Winarni, Rina Wahyu. (2010). Representasi Kecantikan Perempuan Dalam Iklan. Jakarta: Jurnal Deiksis Program Studi Desain Komunikasi Visual Universitas Indraprasta PGRI Jakarta. Vol 02 No.02.

Windasari, Anggry. (2017). Pemaknaan Kecantikan Sebagai Puth Jepang Dalam Iklan Shinzui Body Cleanser. Semarang: Jurnal Program Studi Ilmu Komunikasi, Fakultasi Ilmu Komputer, Universitas Dian Nuswantoro (Udinus). Vol. 47, No.1

Wolf, Naomi. 2004. Mitos Kecantikan: Kala Kecantikan Menindas Perempuan. Yogyakarta: Niagara. 